\title{
Acute toxicity of nitrate in Litopenaeus vannamei juveniles at low salinity levels
}

\author{
Inácio Alves Neto $^{1^{*}}$ iD Hellyjúnyor Brandão ${ }^{1}$ (iD) Plínio Schmidt Furtado ${ }^{1}$ i \\ Wilson Wasielesky Jr. ${ }^{1}$ iD
}

${ }^{1}$ Programa de Pós-graduação em Aquicultura, Instituto de Oceanografia, Universidade Federal do Rio Grande (FURG), Cassino, 96210-030, RS, Brasil. E-mail: engpesca.inacio@gmail.com. *Corresponding author.

ABSTRACT: Different technologies have been developed to improve the performance of Litopenaeus vannamei in low salinity, mainly in super-intensive systems like recirculation and BFT (Biofloc Technology System) systems. However, there is an accumulation of toxic nitrogenous compounds to the shrimps such as nitrate, that at high concentrations and depending on the salinity of the culture water can be lethal. Acute toxicity tests allow to analyze the relationship between the compound and other abiotic or biotic variables. The aim of this research was to determine the acute toxicity and safety level of nitrate $\left(\mathrm{N}-\mathrm{NO}_{3}^{-}\right)$for juveniles of L. vannamei at salinities of 5 and $10 \mathrm{~g}$. $\mathrm{L}^{-1}$. For salinity of $5 \mathrm{~g} . \mathrm{L}^{-1}$, a control and 5 treatments were tested, with nitrate concentrations of 100, 500, 1500, 2500 and 3500mg. $L^{-1}$. For salinity of $10 \mathrm{mg} . L^{-1}$, a 4500mg. $L^{-1}$ nitrate concentration was added. Juveniles were exposed to concentrations during 24, 48, 72, 96 hours in static system. The Mean Lethal Concentration ( $L C_{C 50}$ ) was calculated and the recommended safety level for L. vannamei cultivation is 60.05 and $127.61 m g . L^{-}$ ${ }^{I}$ of nitrate for salinities 5 and $10 \mathrm{~g} . \mathrm{L}^{-1}$, respectively.

Key words: median lethal concentration, Pacific white shrimp, brackish water.

Toxicidade aguda do nitrato em juvenis de Litopenaeus vannamei em baixa salinidade

RESUMO: Diferentes tecnologias foram desenvolvidas para melhorar o desempenho do Litopenaeus vannamei em baixa salinidade, principalmente em sistemas super intensivos como sistema de recirculação e BFT (Biofloc Technology System). No entanto, há um acúmulo de compostos nitrogenados tóxicos aos camarões, como o nitrato, que em altas concentrações e dependendo da salinidade da água pode ser letal. Os testes de toxicidade aguda permitem analisar a relação entre o composto e outras variáveis abióticas ou bióticas. O objetivo deste trabalho foi determinar a toxicidade aguda e o nível de segurança do nitrato ( $\left.\mathrm{N}-\mathrm{NO}_{3}^{-}\right)$em juvenis de L. vannamei nas salinidades de 5 e $10 \mathrm{~g}$. $\mathrm{L}^{-1}$. Para a salinidade de $5 \mathrm{~g} . \mathrm{L}^{-1}$, um controle e cinco tratamentos foram testados, com concentrações de nitrato 100, 500, 1500, 2500 e 3500mg. $L^{-1}$. Para salinidade de $10 \mathrm{mg} . \mathrm{L}^{-1}$, foi adicionada uma concentração de nitrato de 4500mg. $L^{-1}$. Os juvenis foram expostos às concentrações durante 24, 48, 72, 96 horas em sistema estático. A Concentração Letal Média $\left(C L_{50}\right)$ foi calculada e o nível de segurança recomendado para o cultivo de L. vannamei é de 60,05 e 127,61 mg. $L^{-1}$ de nitrato para salinidadesde 5 e $10 \mathrm{~g} . \mathrm{L}^{-1}$, respectivamente.

Palavras-chave: concentração letal mediana, camarão branco do Pacífico, água salobra.

\section{INTRODUCTION}

The Pacific white shrimp Litopenaeus vannamei is an euryhaline species that tolerates a wide range of salinity $\left(0.5\right.$ to $\left.40 \mathrm{~g} . \mathrm{L}^{-1}\right)$, which allows it to be reared in low salinity and is already established in several countries, including the USA, Thailand, Ecuador and Israel (BOYD 2001, SAMOCHA et al., 2001). For this reason, studies on the minimum ionic concentrations required for its good zootechnical performance have been developed (CHONGROBLES et al., 2014; ROY et al., 2010) and together with super-intensive cultivation systems such as recirculation and Biofloc Technology System (BFT) provide ability to expand the activity. However, superintensive systems of aquaculture production require high feed input and stocking densities of animals, increasing the deposition of deleterious compounds of water quality and toxic to the shrimp (MUHLERT et al., 2013). Among these compounds, generation and accumulation of nitrogenous products, which are inserted into the system through the degradation of the organic matter, unconsumed food and from the excretion resulting from the metabolism of the animals, are highlighted (BIANCHINI et al., 1996; EBELING et al., 2006).

The main product generated by the protein catabolism of most aquatic organisms and the 
decomposition of organic matter from over-feeding is ammonia (MAILLARD et al., 2005; REGNAULT, 1987). In water it is found in the ionized $\left(\mathrm{NH}_{4}^{+}\right)$and non-ionized $\left(\mathrm{NH}_{3}\right)$ forms which together form the total ammoniacal nitrogen. In systems that reuse water, this compound goes through a nitrification process, resulting in a final form of nitrate- $\mathrm{N}$ through nitrite oxidation (SCHULER et al., 2010).

Nitrate is considered the less toxic form among nitrogen compounds, but at high concentrations and depending on the salinity of the water, it can be lethal. The conversion of pigments responsible for the transport of oxygen, such as hemocyanin, in forms incapable of carrying out transportation (metahemocyanin) is the main toxic action of nitrate in aquatic animals, reducing the availability of oxygen for metabolism and may induce hypoxia and mortality (CHENG \& CHEN, 2002; JENSEN, 1996; SCOTT \&CRUNKILTON, 2000; TAHON et al., 1988).

Acute toxicity tests represent a standard method for quantifying and comparing the relative toxicities of pollutants and are defined by the concentration that kills $50 \%$ of the test population, known as the $\mathrm{LC}_{50}$ value (APHA, 1998). The $\mathrm{LC}_{50}$ values can be presented from 12 to 24 hours exposure to pollutant concentrations at intervals of up to 96 hours. In addition to providing comparable data for other species or pollutants, these values allow us to analyze the relationships between the compound and other abiotic or biotic variables.

Several studies have been conducted to determine the acute toxicity of nitrogenous compounds in shrimp (CAMPOS et al., 2012; GROSS et al., 2004; SCHULER et al., 2010; TSAI \& CHEN, 2002; WICKINS, 1976). However, until the present study, data for low salinities is still scarce. The aim of this research was to determine the acute toxicity and safety level for nitrate $\left(\mathrm{N}_{-} \mathrm{NO}_{3}^{-}\right)$in juveniles of Litopenaeus vannamei at salinities 5 and $10 \mathrm{~g} . \mathrm{L}^{-1}$.

\section{MATERIALS AND METHODS}

\section{Animals and location}

The study was conducted at the Shrimp Production Laboratory of Marine Aquaculture Station (Estação Marinha de Aquacultura - EMA) belonging to the Oceanography Institute of the Federal University of Rio Grande - FURG, located in the city of Rio Grande, Cassino - RS, Brazil (32 $\left.19 \mathrm{~S}, 52^{\circ} 15^{\mathrm{\prime}} \mathrm{W}\right)$. Prior to the experiments, the animals were acclimated to the salinities of 5.0 and $10.0 \mathrm{~g} . \mathrm{L}^{-1}$. L. vannamei juveniles $(1.8 \pm 0.5 \mathrm{~g})$ were stocked in two 700L tanks in a stocking density of 700 shrimps $/ \mathrm{m}^{3}$. The initial salinity of $30 \mathrm{~g} . \mathrm{L}^{-1}$ was gradually reduced, five parts per day until reaching the desired final values. Water quality parameters were maintained at suitable values for species, with the temperature controlled by thermostatic water heaters (Aquarium Heater H-606) and dissolved oxygen kept near saturation point. Water renewals were performed $(50 \%)$ whenever total ammonia nitrogen reached concentrations close to $0.8 \mathrm{mg}$. $\mathrm{L}^{-}$ 1 . During acclimation, animals were fed $2 x$ per day considering a feed rate of $10 \%$ of the biomass.

In the same period, toxicity pre-tests were carried out, exposing shrimp at the concentrations of 500,1000, 2000 and 3000mg.L ${ }^{-1}$ of $\mathrm{N}^{-N_{3}}{ }_{3}^{-}$, in order to determine the minimum and maximum concentrations of nitrate and its effects on survival. From these data it was possible to delineate the experimental treatments.

\section{Experimental design}

Experimental units with 20 liters of useful volume were used with aeration supplied by radial blower and distributed by two air stones diffusers inside each experimental unit. Sea water was diluted with chlorinated and dechlorinated fresh water for each desired salinity. For salinity $5 \mathrm{~g} . \mathrm{L}^{-1}$, a control (without addition of sodium nitrate) and 5 treatments were tested, with concentrations of $\mathrm{N}_{-\mathrm{NO}_{3}}^{-}: 100,500,1500,2500$ and $3500 \mathrm{mg} . \mathrm{L}^{-1}$. For salinity of $10 \mathrm{~g} . \mathrm{L}^{-1}$, a control and 6 treatments in differentconcentrations of $\mathrm{N}-\mathrm{NO}_{3}{ }^{-}$were determined: $100,500,1500,2500,3500$ and $4500 \mathrm{mg}^{-1} \mathrm{~L}^{-1}$. For both salinities, nitrate concentration was obtained through the dilution of $8.5,42.52,127.57,212.62$, 297.66 and $382.70 \mathrm{~g}$ (for $4500 \mathrm{mg} . \mathrm{L}^{-1}$ treatment in salinity 10$)$ of Sodium nitrate $\left(\mathrm{NaNO}_{3}^{-}-\right.$P.A. Synth) in the water, respectively. To maintain the $\mathrm{Na}$ : $\mathrm{K}$ ratio (28: 1),0.156, 0.78, 2.34, 3.9 and $5.46 \mathrm{~g}$ of Potassium Chloride $\left(\mathrm{KCl}^{-}\right)$, respectively, was added in both experiments and $7.02 \mathrm{~g}$ in the treatment with the highest concentration of nitrate in the salinity $10 \mathrm{~g} . \mathrm{L}^{-1}$. Treatments were completely randomized distributed.

Forty-five juveniles were stocked per treatment and monitored daily to verify mortality death criteria adopted was the absence of any type of movement or reaction to mechanical stimuli when touched by a glass rod. Dead animals were immediately removed from experimental units. The exposure times at concentrations were $24,48,72$, 96 hours in static system. During exposure times, shrimps were not fed. 
Water quality

The parameters of water quality were monitored daily. Temperature and dissolved oxygen were measured with the aid of multiparameter water quality meter (YSI - ProODO). The salinity was measured using digital refractometer (Atago, PALUREA). A table top pHmeter (Mettler Toledo) was used to measure $\mathrm{pH}$ and alkalinity was measured according to the methodology proposed by APHA (1998). Concentrations of ammonia (NAT) were monitored daily and nitrate $\left(\mathrm{N}-\mathrm{NO}_{3}{ }^{-}\right)$was measured to verify the concentrations of the compound after addition of $\mathrm{NaNO}_{3}$, according to methodologies proposed by UNESCO (1983) and AMINOT \& CHAUSSEPIED (1983), respectively.

\section{Statistical analysis}

Water quality data were submitted to Levene's homoscedasticity and ShapiroWilk normality tests and after confirmation of these premises a One-Way Analysis of Variance (ANOVA) was performed to verify the significant differences in water quality parameters. When differences were reported $(p<0.05)$, Tukey's test for comparison was applied (ZAR, 1996).

Median Lethal Concentration $\left(\mathrm{LC}_{50}\right)$ and confidence interval $(95 \% \mathrm{CI})$ were calculated using the Trimmed Spearman-Karber Method software (HAMILTON et al., 1977). To calculate the safety levels (concentration of the compound that does not have an adverse effect on the organisms) for each salinity, the value of $\mathrm{LC}_{50} 96 \mathrm{~h}$ was multiplied by an application factor proposed by SPRAGUE (1971) $\left(\mathrm{LC}_{50} 96 \mathrm{~h}^{*} 0.1\right)$.

\section{RESULTS}

Water quality parameters remained within the ranges considered appropriate for the species studied (LIN AND CHEN, 2003, 2001; WYK et al., 1999) and presented differences only in dissolved oxygen levels. The data are presented in tables 1 and 2 .

Actual concentrations of nitrate measured were similar to the nominal concentrations, with small variations between nominal concentrations and replicates. Themeanvalues of $\mathrm{NO}_{3}{ }^{-}$ranged from- $-0.39 \%$ to $2.38 \%$ of the nominal concentrations $(99.61 \pm 0.83$, $503.15 \pm 2.77, \quad 1507.92 \pm 7.95, \quad 2504.57 \pm 26.41$, $3547.13 \pm 55.43$ and $4606.94 \pm 104.75 \mathrm{mg} . \mathrm{L}^{-1}$ of nitrate). To obtain compound concentrations in the experimental units, high purity reagents were used which was representative by comparing actual and nominal concentrations. The differences reported in this study for the variations between nominal and real concentrations were smaller than those described in other studies such as TSAI \& CHEN (2002) and SOUCEK \& DICKINSON (2012).

Figures 1 and 2 illustrate that there was mortality in the control group (without addition of nitrate) in both experiments starting from $60 \mathrm{~h}$. In 24 hours, the treatment with $3500 \mathrm{mg} . \mathrm{L}^{-1}$ of nitrate reached $100 \%$ of mortality when in salinity of $5 \mathrm{~g} . \mathrm{L}^{-1}$. For the same period and at the highest concentration, 4,500mg. $\mathrm{L}^{-1}, 93.33 \%$ mortality was observed in salinity 10 .

After $96 \mathrm{~h}, 100 \%$ of mortality was reported in the highest concentration, 3,500mg. $\mathrm{L}^{-1}$ followed by $97.77 \%, 80 \%, 44.44 \%, 13.33 \%, 8.88 \%$ for 2,500 , 1,500, 500 and $100 \mathrm{mg} . \mathrm{L}^{-1} \mathrm{NO}_{3}{ }^{-}$concentrations. As in the previous one, $100 \%$ lethality was obtained for the highest nitrate concentration, 4,500mg. $\mathrm{L}^{-1}$, followed

Table 1 - Water quality parameters during the $\mathrm{LC}_{50}$ test for salinity $5 \mathrm{~g} . \mathrm{L}^{-1}$ under different concentrations of nitrate $\left(\mathrm{N}^{-N O_{3}}{ }^{-}\right)$.

\begin{tabular}{lccccc}
\hline & Temperature & DO & pH & TAN & Alkalinity \\
\hline Control & $27.95 \pm 1.62$ & $7.20 \pm 0.15^{\mathrm{ab}}$ & $8.13 \pm 0.11$ & $0.40 \pm 0.26$ & $97.5 \pm 2.54$ \\
100 & $27.84 \pm 1.80$ & $7.32 \pm 0.15^{\mathrm{ab}}$ & $8.12 \pm 0.11$ & $0.40 \pm 0.26$ & $97.5 \pm 2.55$ \\
500 & $28.14 \pm 0.11$ & $7.41 \pm 0.09^{\mathrm{a}}$ & $8.12 \pm 0.11$ & $0.42 \pm 0.27$ & $97.5 \pm 2.56$ \\
1500 & $27.99 \pm 2.26$ & $6.86 \pm 0.06^{\mathrm{b}}$ & $8.17 \pm 0.11$ & $0.41 \pm 0.26$ & $97.5 \pm 2.59$ \\
2500 & $28.03 \pm 1.69$ & $6.98 \pm 0.03^{\mathrm{b}}$ & $8.15 \pm 0.11$ & $0.41 \pm 0.26$ & $97.5 \pm 2.55$ \\
3500 & $27.89 \pm 1.79$ & $7.22 \pm 0.18^{\mathrm{ab}}$ & $8.13 \pm 0.10$ & 0.55 \\
\hline
\end{tabular}

The data correspond to mean values of three replicates \pm standard deviation. Different letters on the same column indicate that means differ significantly $(\mathrm{p}<0.05)$. Temperature $\left({ }^{\circ} \mathrm{C}\right)$; DO - Dissolved oxygen $\left(\mathrm{mg} . \mathrm{L}^{-1}\right)$; TAN - Total ammonia nitrogen $\left(\mathrm{mg} . \mathrm{L}^{-1}\right)$; Alkalinity $\left(\mathrm{mg}\right.$ of $\left.\mathrm{CaCO}_{3} \cdot \mathrm{L}^{-1}\right)$. 
Table 2 - Water quality parameters during the $\mathrm{LC}_{50}$ test for salinity $10 \mathrm{~g} \cdot \mathrm{L}^{-1}$ under different concentrations of nitrate $\left(\mathrm{N}-\mathrm{NO}_{3}{ }^{-}\right)$.

\begin{tabular}{lccccc}
\hline & Temperature & DO & pH & TAN & Alkalinity \\
\hline Control & $27.01 \pm 0.50$ & $6.74 \pm 0.1^{\mathrm{a}}$ & $8.20 \pm 0.09$ & $0.35 \pm 0.25$ & $97.5 \pm 2.54$ \\
100 & $26.9 \pm 0.49$ & $6.75 \pm 0.11^{\mathrm{a}}$ & $8.20 \pm 0.10$ & $0.34 \pm 0.23$ & $97.5 \pm 2.58$ \\
500 & $27.06 \pm 0.51$ & $6.70 \pm 0.09^{\mathrm{a}}$ & $8.18 \pm 0.10$ & $0.35 \pm 0.26$ & $97.5 \pm 2.57$ \\
1500 & $26.7 \pm 0.46$ & $6.8 \pm 0.13^{\mathrm{a}}$ & $8.18 \pm 0.07$ & $0.37 \pm 0.24$ & $97.5 \pm 2.61$ \\
2500 & $27.02 \pm 0.52$ & $6.72 \pm 0.10^{\mathrm{a}}$ & $8.20 \pm 0.10$ & $0.33 \pm 0.26$ & $97.5 \pm \pm 0.24$ \\
3500 & $26.9 \pm 0.49$ & $6.75 \pm 0.12^{\mathrm{a}}$ & $8.19 \pm 0.09$ & $0.36 \pm 0.26$ \\
4500 & $28.27 \pm 0.22$ & $7.46 \pm 0.00^{\mathrm{b}}$ & $8.17 \pm 0.12$ & $97.5 \pm 2.73$ \\
\hline
\end{tabular}

The data correspond to mean values of three replicates \pm standard deviation. Different letters on the same column indicate that means differ significantly $(\mathrm{p}<0.05)$. Temperature $\left({ }^{\circ} \mathrm{C}\right)$; DO - Dissolved oxygen $\left(\mathrm{mg} . \mathrm{L}^{-1}\right)$; TAN - Total ammonia nitrogen $\left(\mathrm{mg} . \mathrm{L}^{-1}\right)$; Alkalinity $\left(\mathrm{mg}\right.$ of $\left.\mathrm{CaCO}_{3} \cdot \mathrm{L}^{-1}\right)$.

by $95.55 \%, 88.88 \%, 60 \%, 13.33 \%, 26.66 \%$ and 13.33 respectively for the treatments with 3500 , 2500, 1500, 500 and $100 \mathrm{mg} . \mathrm{L}^{-1} \mathrm{NO}_{3}^{-}$in salinity of 10.

Figures 3 and 4 a linear negative relationship between the $\mathrm{LC}_{50}$ lethal concentration and exposure time was shown in two salinities, 5 and $10 \mathrm{~g} . \mathrm{L}^{-1}$. Results of Mean Lethal Concentration $\left(\mathrm{LC}_{50}\right)$ as well as the confidence intervals for each salinity $(95 \% \mathrm{CI})$ are presented in table 3 . The acute toxicity of nitrate was tested for several species of crustaceans, especially for penaeids, as shown in table 4.

\section{DISCUSSION}

The material presented in this research adds to the current knowledge more data about the sensitivity of the penaeid shrimp Litopenaeus vannamei to the nitrate. Although, there are studies on acute toxicity to some aquatic organisms (CAMARGO et al., 2005; PANDEY et al., 2011; SOUCEK \& DICKINSON, 2012) there is still a demand for more information of the effects on this species, especially at low salinity. In aquaculture it is important to know the limits of tolerance of the species that is aimed to be cultivated since the parameters of water quality are determinant factors for the maintenance of cultivation systems.

CAMPOS et al. (2012) tested $\mathrm{LC}_{50}$ values for juveniles of Farfantepenaeus brasiliensis and their respective confidence intervals at salinity 28g.L. ${ }^{-1}$ and found 912.07mg.L. (LC $\left._{50}-96 \mathrm{~h}\right)$. Based on the application factor proposed by SPRAGUE (1971), the calculated safety level for juveniles of $F$. brasiliensis is $91.20 \mathrm{mg} . \mathrm{L}^{-1}$.TSAI \& CHEN (2002) conducted an acute nitrate toxicity test in Penaeus monodon, using the same empirical application factor presented to estimate safe chronic levels and reported a value of $145 \mathrm{mg} . \mathrm{L}^{-1}$ of nitrate in $15 \mathrm{~g} . \mathrm{L}^{-1}$ of salinity.

In the present study we reported values for salinities 5 and $10 \mathrm{~g} . \mathrm{L}^{-1}$ of 600.51 and $1276.29 \mathrm{mg} . \mathrm{L}^{-1}$, respectively, with safety levels 60.05 and 127.61, thus showing that $L$. vannamei is sensitive to nitrate; however, according to the data generated in this

Table $3-\mathrm{LC}_{50}\left(\mathrm{mg} . \mathrm{L}^{-1}\right)$ and confidence intervals of $\mathrm{N}^{-\mathrm{NO}_{3}}{ }^{-}$at different times and salinities.

\begin{tabular}{lcc}
\hline Time $(\mathrm{h})$ & $5 \mathrm{~g} . \mathrm{L}^{-1}$ & $10 \mathrm{~g} . \mathrm{L}^{-1}$ \\
\hline 24 & $1385.38(1163.29-1649.87)$ & $2716.12(2445.69-3016.46)$ \\
48 & $1052.58(859.72-1288.72)$ & $1860.64(1611.66-2148.08)$ \\
72 & $768.09(614.49-960.09)$ & $2006.89(1764.00-2282.70)$ \\
96 & $600.51(467.23-771.81)$ & $1276.09(1090.07-1495.07)$ \\
\hline
\end{tabular}

Ciência Rural, v.49, n.1, 2019. 
Table $4-\mathrm{LC}_{50}-96 \mathrm{~h}$ values $\left(\mathrm{mg} \mathrm{N}-\mathrm{NO}_{3}{ }^{-} \cdot \mathrm{L}^{-1}\right)$ of nitrate for juveniles of different species of crustaceans, including results generated by the present study.

\begin{tabular}{|c|c|c|c|c|}
\hline Species & Life stage & Salinity & $\mathrm{LC}_{50}$ & References \\
\hline \multirow{3}{*}{ Penaeus monodon } & \multirow{3}{*}{ Juvenile } & 15 with $\mathrm{K}^{+}$ & 1411 & ROMANO \& ZENG (2009) \\
\hline & & 35 no K $^{+}$ & 2213 & ROMANO \& ZENG (2009) \\
\hline & & 35 with $\mathrm{K}^{+}$ & 2337 & ROMANO \& ZENG (2009) \\
\hline \multirow[t]{2}{*}{ Penaeus monodon } & Juvenile $(0.30 \mathrm{~g})$ & 15 & 1449 & TSAI \& CHEN (2002) \\
\hline & & 35 & 2316 & TSAI \& CHEN (2002) \\
\hline \multirow[t]{2}{*}{ Scylla serrata } & - & 30 no $^{+}$ & 3601 & ROMANO \& ZENG (2007) \\
\hline & & 30 with $\mathrm{K}+$ & 4339 & ROMANO \& ZENG (2007) \\
\hline \multirow{2}{*}{ Portunus pelagicus } & \multirow{2}{*}{ Juvenile (0.24 g) } & 30 no $^{+}$ & 3355 & ROMANO \& ZENG (2007) \\
\hline & & 30 with $\mathrm{K}+$ & 4132 & ROMANO \& ZENG (2007) \\
\hline Farfantepenaeus brasiliensis & Juvenile $(0.30 \mathrm{~g})$ & 28 & 912.07 & CAMPOS et al (2012) \\
\hline \multirow{2}{*}{ Litopenaeus vannamei } & \multirow{2}{*}{ Juvenile (1.8g) } & 5 & 600.51 & This study \\
\hline & & 10 & 1276.09 & This study \\
\hline
\end{tabular}

$\mathrm{LC}_{50}=$ Median Lethal Concentration (mg. $\left.\mathrm{L}^{-1}\right)$.

study, it is more resistant than Brazil pink shrimp and tiger shrimp.

Also, according to $\mathrm{LC}_{50}$ it was possible to show in this study that salinity is a determining factor for nitrate toxicity, since it is directly proportional to salinity. According to TSAI \& CHEN (2002), nitrate toxicity decreases with increasing salinity. KUHN et al. (2010) showed an increase in mortality of $L$. vannamei when submitted to the reduction of salinity in higher nitrate concentrations.

Studies by FURTADO et al. (2014) showed lethal effect on penaeid shrimp exposed

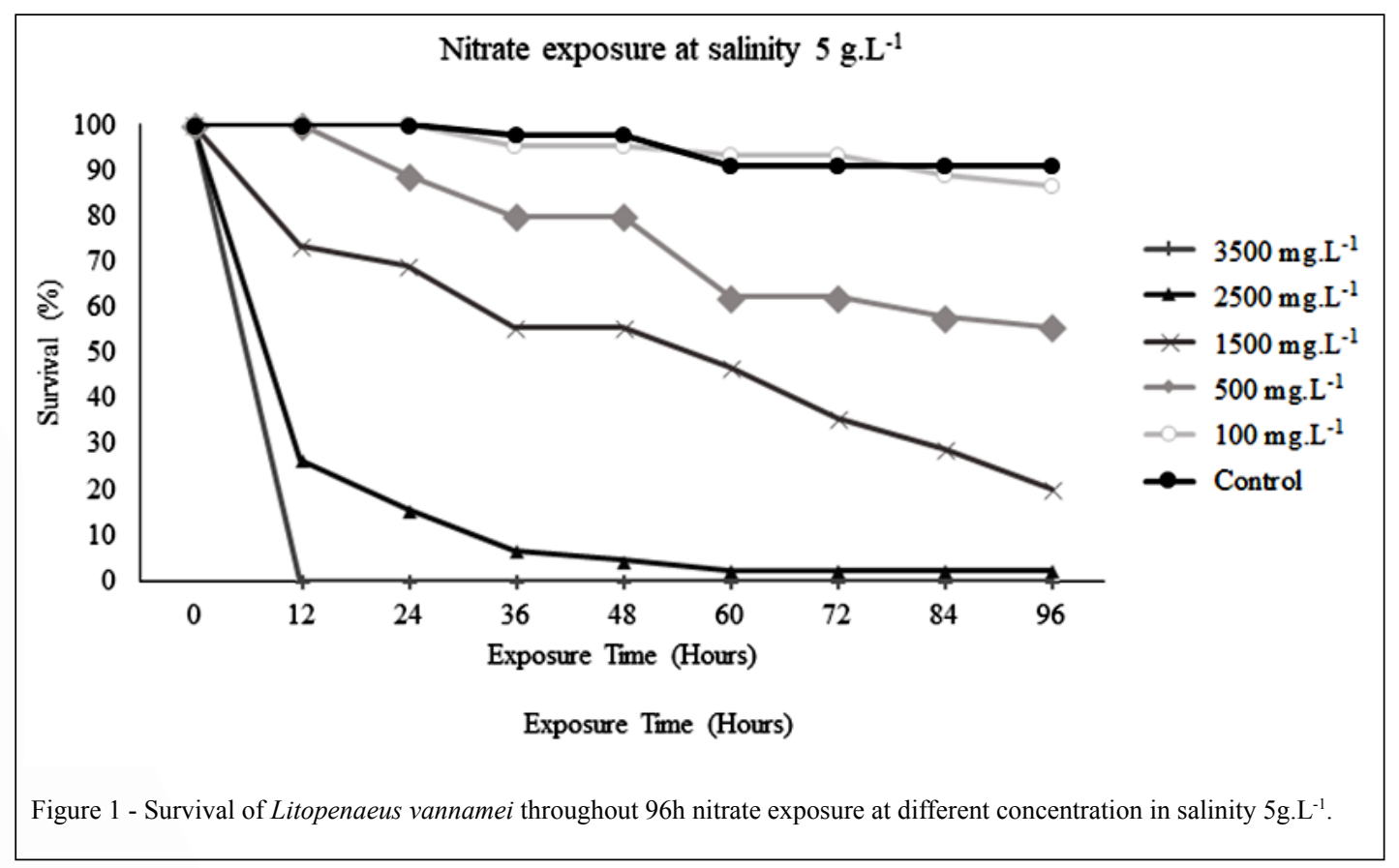

Ciência Rural, v.49, n.1, 2019. 


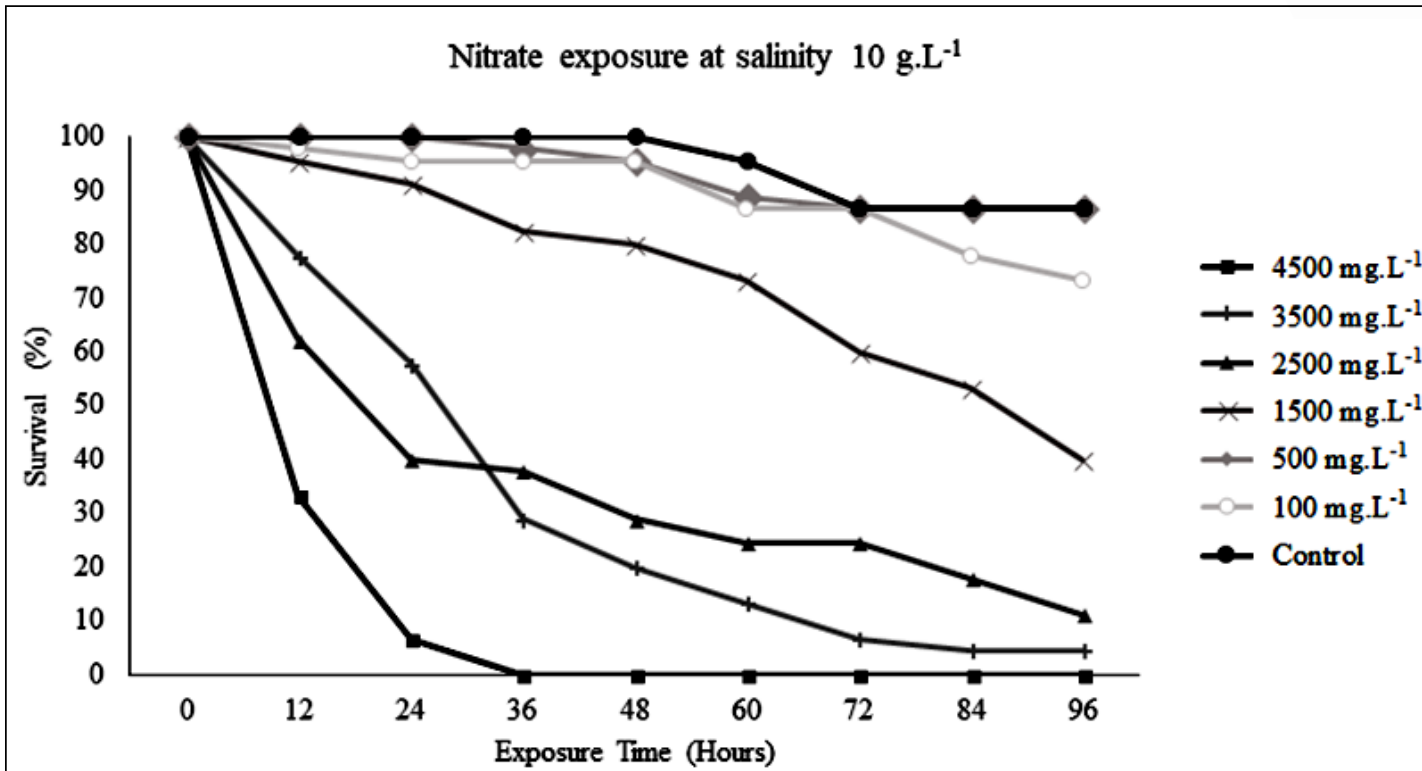

Figure 2 - Survival of Litopenaeus vannamei throughout $96 \mathrm{~h}$ nitrate exposure at different concentration in salinity $10 \mathrm{~g} . \mathrm{L}^{-1}$.

to concentrations above $300 \mathrm{mg} . \mathrm{L}^{-1}$ in salinity of 24 and levels below $220 \mathrm{mg} . \mathrm{L}^{-1}$ for salinity 11 was reported by KUHN et al. (2010). In addition, the accumulation of this nitrogen compound can cause sublethal effects on organisms, such as affecting antenna length, gill injury, hepatopancreas lesions, and other deleterious effects (FURTADO et al. 2014).

Closed aquaculture systems with little or no water exchange, such as recirculation and bioflocs systems, depend on nitrification for the conversion of ammonia nitrogen to nitrate, which

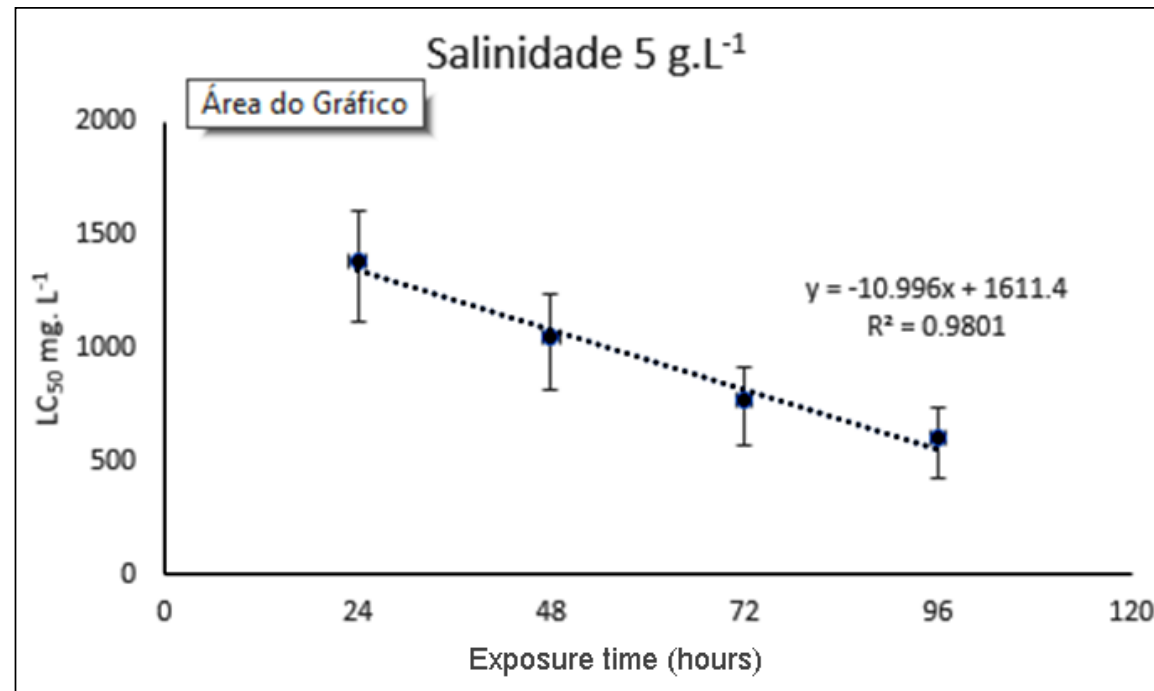

Figure 3 - Linear regression of $\mathrm{LC}_{50}$ of nitrate-N to juvenile of $L$. vannamei exposed to different concentrations of nitrate- $\mathrm{N}$ at salinity $5 \mathrm{~g} \cdot \mathrm{L}^{-1}$.

Ciência Rural, v.49, n.1, 2019. 


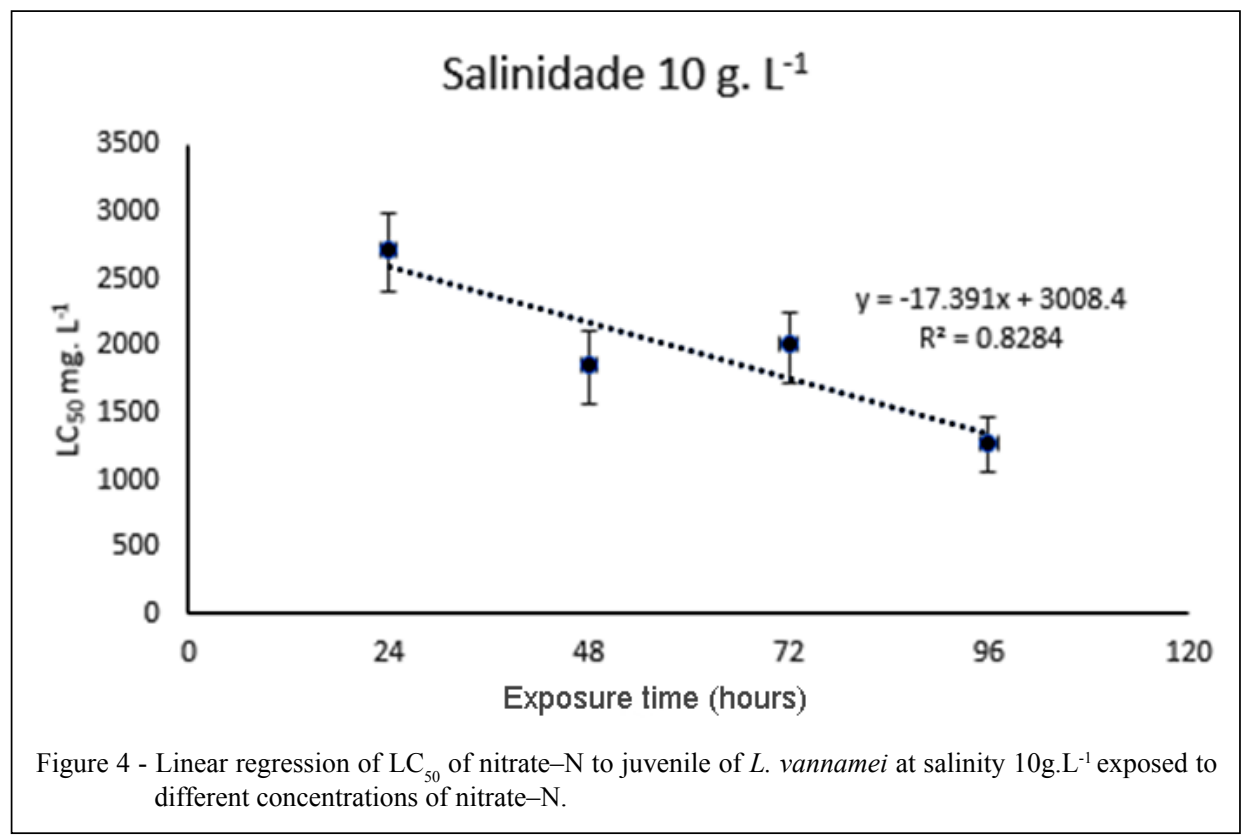

leads to the accumulation of the last one. Although less toxic, nitrate has lethal effect for organisms when in high concentrations. Some ways have been studied to remove and use this compound, such as the use of biofilters and integrated multitrophic aquaculture systems, which $t$ is the production of food such as fish, shrimp, mollusk, combined with an organism with market value, using plants for nitrate assimilation, reducing and/or recycling this compound (RAKOCY et al., 2006; VAN RIJN, 2013). Another technology under investigation for application in aquaculture is the electrochemical treatment (MOOK et al., 2012), where the nitrate is reduced to the nitrogen gas at the cathode.

\section{CONCLUSION}

Based on the values found for $\mathrm{LC}_{50}$ in $96 \mathrm{~h}$, the recommended safety level for $L$. vannamei cultivation is 60.05 and $127.61 \mathrm{mg} . \mathrm{L}^{-1}$ of nitrate for the salinities of 5 and $10 \mathrm{~g} . \mathrm{L}^{-1}$, respectively. To reuse water during several cycles of cultivation with low salinity in super-intensive systems, it is recommended the use of mechanisms and management to remove or immobilize this compound so that its toxicity does not compromise the development of the organisms cultivated, avoiding losses in the production.

\section{ACKNOWLEDGEMENTS}

This work was supported by the Conselho Nacional de Desenvolvimento Científico e Tecnológico (CNPq), Coordenação de Aperfeiçoamento de Pessoal de Nível Superior (CAPES) and Fundação de Amparo à Pesquisa do Estado do Rio Grande do Sul (FAPERGS). Wasielesky, W.J. is a research fellow of CNPq under process number: 310652/2017-0.

\section{DECLARATION OF CONFLICTING INTERESTS}

The authors declare no conflict of interest. The founding sponsors had no role in the design of the study; in the collection, analyses, or interpretation of data; in the writing of the manuscript and in the decision to publish the results.

\section{AUTHORS' CONTRIBUTIONS}

Alves Neto, Furtado and Wasielesky Jr conceived and designed experiments. Brandão performed statistical analyses of experimental data. All authors contributed equally for the conception and writing of the manuscript. All authors critically revised the manuscript and approved of the final version.

\section{REFERENCES}

AMERICAN PUBLIC HEALTH ASSOCIATION (APHA). Standard methods for the examination of water and wastewaterWashington, DC, 20st edition, 1998.

AMINOT, A, CHAUSSEPIED M. Manuel des analyses chimiques en milieu marin. Brest, CNEXO. 1983. 
BOYD, C. E. Inland shrimp farming and the environment. WorldAquaculture, 2001. 32( 1): 10-12.

BIANCHINI, A. et al. Toxicity of nitrogenous compounds to juveniles of flatfish Paralichthys orbignyanus. Bulletin of Environmental Contamination and Toxicology, v.56, n.3, p.453-459. 1996. Available from: <https://link.springer.com/ article/10.1007/s001289900065>. Accessed: Mar. 12, 2018. doi: $10.1007 / \mathrm{s} 001289900065$

CAMARGO, J. A. et al. Nitrate toxicity to aquatic animals: A review with new data for freshwater invertebrates. Chemosphere, v.58, n.9, p.1255-1267, 2005. Available from: <https://doi. org/10.1016/j.chemosphere.2004.10.044>. Accessed: Mar. 12, 2018. doi: 10.1016/j.chemosphere.2004.10.044.

CAMPOS, B. R. DE et al. Toxicidade Aguda Da Amônia, Nitrito E Nitrato Sobre Os Juvenis De Camarão Rosa Farfantepenaeus brasiliensis (Latreille, 1817) (Crustacea: Decapoda). Atlântica 2012. v.34, n.1, p.75-81. Available from: <http://www.seer.furg.br/ atlantica/article/view/2712/1488 $>$. Accessed: Mar. 12, 2018. doi: 10.5088/at1.2012.34.1.75

CHENG, S. Y.; CHEN, J. C. Joint action of elevated ambient nitrite and nitrate on hemolymph nitrogenous compounds and nitrogen excretion of tiger shrimp Penaeus monodon. Comparative Biochemistry and Physiology - C Toxicology and Pharmacology, v.131, n.3, p.303-314, 2002. Available from: <https://www sciencedirect.com/science/article/pii/S1532045602000042>. Accessed: Mar. 12, 2018. doi: 10.1016/S1532-0456(02)00004-2.

CHONG-ROBLES, J. et al. Osmoregulation pattern and salinity tolerance of the white shrimp Litopenaeus vannamei (Boone, 1931) during post-embryonic development. Aquaculture, v.422-423, p.261-267, 2014. Available from: <http://dx.doi. org/10.1016/j.aquaculture.2013.11.034>. Accessed: Mar. 12, 2018. doi: 10.1016/j.aquaculture.2013.11.034.

EBELING, J. M. et al. Engineering analysis of the stoichiometry of photoautotrophic, autotrophic, and heterotrophic removal of ammonia-nitrogen in aquaculture systems. Aquaculture, v.257, n.1-4, p.346-358, 2006. Available from: <https://www.sciencedirect.com/science/ article/pii/S004484860600216X>. Accessed: Mar. 12, 2018. doi: 10.1016/j.aquaculture.2006.03.019.

FURTADO, P. S. et al. Effects of nitrate toxicity in the Pacific white shrimp, Litopenaeus vannamei, reared with biofloc technology (BFT). Aquaculture International, v.23, n.1, p.315-327, 2014. Available from: <https://link.springer.com/ article/10.1007/s10499-014-9817-z>. Accessed: Mar. 12, 2018. doi: 10.1007/s10499-014-9817-z

GROSS, A. et al. Acute and Chronic Effects of Nitrite on White Shrimp, Litopenaeus vannamei, Cultured in Low-Salinity Brackish Water. Journal of the World Aquaculture Society, v.35, n.3, p.315-321, 2004. Available from: <https://onlinelibrary.wiley. com/doi/abs/10.1111/j.1749-7345.2004.tb00095.x>. Accessed: Mar. 12, 2018. doi: 10.1111/j.1749-7345.2004.tb00095.x.

HAMILTON, M. A.; et al., Trimmed Spearman-Karber method for estimating median lethal concentrations in toxicity biossays. Environmental Science \& Technology, v.11, n.7, p.714-719, 1977. Available from: <https://pubs.acs.org/doi/abs/10.1021/es6 0130a004? journalCode $=$ esthag $>$. Accessed: Mar. 12, 2018. doi: 10.1021/es60130a004.
JENSEN, F. B. Uptake, elimination and effects of nitrite and nitrate in freshwater crayfish (Astacus astacus). Aquatic Toxicology, v.34, n.2, p.95-104, 1996. Available from: <https://www.sciencedirect. com/science/article/pii/0166445X95000308>. Accessed: Mar. 12, 2018. doi: 10.1016/0166-445X(95)00030-8.

KUHN, D. D. et al. Chronic toxicity of nitrate to Pacific white shrimp, Litopenaeus vannamei: Impacts on survival, growth, antennae length, and pathology. Aquaculture, v.309, n.1-4, p.109-114, 2010. Available from: <http://dx.doi.org/10.1016/j. aquaculture.2010.09.014>. Accessed: Mar. 12, 2018. doi: 10.1016/j.aquaculture.2010.09.014.

LIN, Y. C.; CHEN, J. C. Acute toxicity of ammonia on Litopenaeus vannamei (Boone) juveniles at different salinity levels. Journal of Experimental Marine Biology and Ecology, v.259, n.1, p.109-119, 2001. Available from: <https://www.sciencedirect. com/science/article/pii/S0022098101002271>. Accessed: Mar. 12, 2018. doi: 10.1016/S0022-0981(01)00227-1.

LIN, Y. C.; CHEN, J. C. Acute toxicity of nitrite on Litopenaeus vannamei (Boone) juveniles at different salinity levels. Aquaculture, v.224, n.1-4, p.193-201, 2003. Available from: $\quad<$ https://www.sciencedirect.com/science/article/abs/pii/ S0044848603002205>. Accessed: Mar. 12, 2018. doi: 10.1016/ S0044-8486(03)00220-5.

MAILLARD, V. M. et al. Water quality and sludge characterization at raceway-system trout farms. Aquacultural Engineering, v.33, n.4, p.271-284, 2005. Available from: <https://www.sciencedirect. com/science/article/pii/S0144860905000324>. Accessed: Mar. 12, 2018. doi: 10.1016/j.aquaeng.2005.02.006

MOOK, W. T. et al. Removal of total ammonia nitrogen (TAN), nitrate and total organic carbon (TOC) from aquaculture wastewater using electrochemical technology: A review. Desalination, v.285, p.1-13, 2012. Available from: <http://dx.doi.org/10.1016/j. desal.2011.09.029>. Accessed: Mar. 12, 2018. doi: 10.1016/j. desal.2011.09.029

MUHLERT, A. et al. Indicadores Numéricos Como Ferramenta Para Avaliação Da Sustentabilidade Ecológica Da Carcinicultura Marinha Em Sergipe, Brasil/Numerical Indicators As a Tool for the Evaluation of the Ecological Sustainability of Marine Shrimp Farms in Sergipe, Brazil. Interciencia, v.38, n.8, p.615-620, 2013. Available from: $<$ https://www.interciencia.net/wp-content/uploads/2017/12/615-cMUHLERT-6.pdf>. Accessed: Mar. 12, 2018.

PANDEY, R. B.; et al. Survival and precopulatory guarding behavior of Hyalella azteca (Amphipoda) exposed to nitrate in the presence of atrazine. Environmental Toxicology and Chemistry, v.30, n.5, p.1170-1177, 2011. Available from: <https://www.ncbi.nlm.nih.gov/ pubmed/21309026>. Accessed: Mar. 12, 2018. doi: 10.1002/etc.473.

RAKOCY, J. E. et al. Recirculating aquaculture tank production systems: Aquaponics- integrating fish and plant culture. SRAC Publication - southern regional aquaculture center, n.454, p.16, 2006. Available from: <http://www.gemstone.umd.edu/team-sites/ classof2014/mega/documents/Rakocy RAS.PDF>. Accessed: Mar. 12, 2018

REGNAULT, M. Nitrogen Excretion In Marine and FreshWater Crustacea. Biological Reviews, v.62, n.1, p.1-24, 1987. Available from: <https://onlinelibrary.wiley.com/doi/abs/10.1111/ j.1469-185X.1987.tb00623.x>. Accessed: Mar. 12, 2018. doi: 10.1111/j.1469-185X.1987.tb00623.x.

Ciência Rural, v.49, n.1, 2019. 
ROMANO, N.; ZENG, C. Acute toxicity of sodium nitrate, potassium nitrate, and potassium chloride and their effects on the hemolymph composition and gill structure of early juvenile blue swimmer crabs (Portunus pelagicus Linnaeus, 1758) (Decapoda, Brachyura, Portunidae). Environmental Toxicology and Chemistry, v.26, n.9, p.1955-1962, 2007. Available from: $<$ https://www.ncbi.nlm.nih.gov/pubmed/17705664>. Accessed: Mar. 12, 2018. doi: 10.1897/07-144R.1.

ROMANO, N.; ZENG, C. Evaluating the newly proposed protocol of incorporated potassium in nitrate toxicity experiments at different salinities: A case study with the tiger prawn, Penaeus monodon, juveniles. Aquaculture, v.289, n.3-4, p.304-309, 2009. Available from: <http://dx.doi.org/10.1016/j. aquaculture.2009.01.035>. Accessed: Mar. 12, 2018. doi 10.1016/j.aquaculture.2009.01.035.

ROY, L. A. et al. Shrimp culture in inland low salinity waters. Reviews in Aquaculture, v.2, n.4, p.191-208, 2010 Available from: <https://onlinelibrary.wiley.com/doi/full/10.11 11/j.1753-5131.2010.01036.x>. Accessed: Mar. 12, 2018. doi 10.1111/j.1753-5131.2010.01036.x.

SAMOCHA, T. M. et al. Development of integrated, environmentally sound, inland shrimp production technologies for Litopenaeus vannamei. World Aquaculture Society, p.64-75, 2001. Available from: < http://fau.digital.flvc.org/islandora/object/ fau\%3A6572>. Accessed: Mar. 12, 2018.

SCHULER, D. J. et al. Acute toxicity of ammonia and nitrite to pacific white shrimp, Litopenaeus vannamei, at low salinities. Journal of the World Aquaculture Society, v.41, n.3, p.438-446, 2010. Available from: <https://onlinelibrary.wiley.com/doi/full/10 $.1111 / \mathrm{j} .1749-7345.2010 .00385 . \mathrm{x}>$. Accessed: Mar. 12, 2018. doi: 10.1111/j.1749-7345.2010.00385.x.

SCOTT, G.; CRUNKILTON, R. Acute and chronic toxicity of nitrate to fathead minnows (Pimephales promelas), Ceriodaphnia dubia, and Daphnia magna. Environmental Toxicology and Chemistry, v.19, n.12, p.2918-2922, 2000. Available from: $<$ http://onlinelibrary.wiley.com/doi/10.1002/etc.5620191211/ full>. Accessed: Mar. 12, 2018. doi: 10.1002/etc.5620191211.

SOUCEK, D. J.; DICKINSON, A. Acute toxicity of nitrate and nitrite to sensitive freshwater insects, mollusks, and a crustacean. Archives of Environmental Contamination and Toxicology, v.62, n.2, p.233-242, 2012. Available from: <https://www.ncbi. nlm.nih.gov/pubmed/21877224>. Accessed: Mar. 12, 2018. doi: $10.1007 / \mathrm{s} 00244-011-9705-8$
SPRAGUE, J. B. Measurement of pollutant toxicity to fishIII: Sublethal concentrations and "safe" concentrations. Water Research, v.5, n.6, p.245-266, 1971. Available from: $<$ https://www. sciencedirect.com/science/article/abs/pii/0043135471901710>. Accessed: Mar. 12, 2018. doi: 10.1016/0043-1354(71)90171-0.

TAHON, J. P. et al.The reaction of nitrite with the haemocyanin of Astacus leptodactylus. The Biochemical journal, v.249, n.3, p.891-6, 1988. Available from: <https://www.ncbi.nlm.nih.gov/ pmc/articles/PMC1148790/>. Accessed: Mar. 12, 2018.

TSAI, S. J.; CHEN, J. C. Acute toxicity of nitrate on Penaeus monodon juveniles at different salinity levels. Aquaculture, v.213, n.1-4, p.163-170, 2002. Available from: <https://www.sciencedirect.com/science/article/abs/pii/ S0044848602000236>. Accessed: Mar. 12, 2018. doi: 10.1016/ S0044-8486(02)00023-6

UNESCO. Chemical methods for use in marine environmental monitoring. Manual and Guides 12, Intergovernmental Oceanographic Commission, Paris, France, 1983.

VAN RIJN, J. Waste treatment in recirculating aquaculture systems. Aquacultural Engineering, v.53, n.2010, p.49-56, 2013. Available from: $<$ http://dx.doi.org/10.1016/j.aquaeng.2012.11.010 $>$. Accessed: Mar. 12, 2018. doi: 10.1016/j.aquaeng.2012.11.010.

WICKINS, J. F. The tolerance of warm-water prawns to recirculated water. Aquaculture, v.9, n.C, p.19-37, 1976. Available from: <https://www.sciencedirect.com/science/article/ abs/pii/0044848676900454>. Accessed: Mar. 12, 2018. doi: 10.1016/0044-8486(76)90045-4.

WYK, P. Van et al. Farming Marine Shrimp in Recirculating Fresh Water Systems. Florida Department of Agriculture and Consumer Services, n.4520, 1999. Available from: <https:// www.researchgate.net/publication/242621708_Farming_Marine Shrimp_in_Recirculating_Fresh_Water_Systems $>$. Accessed: Mar. 12, 2018.

ZAR, JH., Biostatistical analysis. Prentice Hall, New Jersey, $3^{\text {rd }}$ edn, 1996. 